\section{Molybdenum Nutrition and Free Amino-Acids in Tomato}

J. V. Possingham has obtained some interesting results in an investigation of the effect of molybdenum on the content of free amino-acids and amides in tomato plants (Austral. J. Biol. Sci., 10, 40; 1957). The plants, which had been cultured in the absence of molybdenum, were provided with molybdate, and the consequent changes in the relative amounts of the free amino-acids and amides were followed over an experimental period of four days. Quantitative paper chromatography was used for estimating the individual free amino-acids and amides, the results being expressed on a dry-weight basis. Changes in the concentrations of many of the individual amino-acids occurred within four hours of applying molybdenum. Large increases in the concentration of aspartic acid, glutamic acid, glycine, glutamine and asparagine occurred initially with molybdenum treatment, but were followed by steady declines. A different pattern of change was shown by the two compounds $\beta$-alanine and $\gamma$-aminobutyric acid, both of which decreased in concentration soon after molybdenum was applied. The results of this investigation are discussed in relation to the pathway by which the products of nitrate reduction are incorporated into proteins.

\section{Mathematical Colloquium at University College, Cork}

Aвоuт thirty delegates from Irish universities, the Dublin Institute for Advanced Studies and the Irish Civil Service attended a mathematical colloquium at University College, Cork, during July 10-12. Profs. M. H. A. Newman and G. Temple gave short courses of lectures on mathematical logic and the theory of distributions, and splinter groups in algebra, analysis and applied mathematics were also organized. It is hoped to arrange an Irish mathematical colloquium at regular intervals in future. Inquiries should be addressed to the Organizing Secretary, Cork Mathematical Colloquium, Department of Mathematical Physics, University College, Cork.

\section{Forestry and the United Nations}

AN interesting and informative article on the forest work of the Food and Agriculture Organization of the United Nations by Sir H. Beresford Pierce appears in Forestry (30, No. 1.; 1957. Oxford University Press). Forestry is one side only of the work of the Food and Agriculture Organization, which has five divisions-agriculture, economies, nutrition, forestry and fisheries. The forestry work is of a world-wide order, so as to reach backward countries where the aims and objects of scientific forestry are unknown or neglected. The Organization keeps in touch with the needs and wishes of governments all over the world through a number of regional Commissions, including the European Forestry Commission based on Rome, the Near East Commission based on Cairo, the Latin American Commission based on Rio de Janeiro and the Asian Pacific Forestry Commission based on Bangkok. Because of its special problems there is also a sub-Commission for the Mediterranean area. There is no commission as yet for North America, nor for West Africa south of the Sahara, although the latter is a region where there is much to be done in the forestry line.

A World Forest Inventory, which has been one of the objects of the forestry work of the United
Nations, was first completed in 1948; the second, an appreciably better assessment, appeared in 1953 ; and a third is planned for 1958 .

\section{Announcements}

Dr. Richard E. Shope, of the Rockefeller Institute, has been awarded the George M. Kober Medal of the Association of American Physicians for his work on the occurrence of animal viruses.

Prof. W. E. Morton, professor of textile technology in the University of Manchester, has been awarded the Warner Memorial Medal for 1957 of the Textile Institute. The Warner Medal is awarded in recognition of outstanding work in textile science and technology, the results of which have been published, and particularly for work published in the Journal of the Textile Institute.

Prof. R. Cruickshank, principal of the WrightFleming Institute of Microbiology, St. Mary's Hospital Medical School, London, has been appointed professor of bacteriology in the University of Edinburgh.

A general meeting of the Association of Applied Biologists will be held in the University of Leeds during September 19-20. Particulars can be obtained from Dr. J. H. Western, Department of Agriculture, The University, Leeds 2.

THE next meeting of the Photoelectric Spectrometry Group will be the ninth annual general meeting and will take the form of a joint meeting with the Photobiology Group to be held in the Old Medical School, University of Liverpool, on September 26. The subject of the meeting will be "The Spectroscopy of the Natural Pigments". The Photobiology Group will also meet on the following day. Details can be obtained from the Honorary Secretary, Photoelectric Spectrometry Group, 56 Arbury Road, Cambridge, or from the Honorary Secretary, Photobiology Group, Chester Beatty Research Institute, Royal Cancer Hospital, Fulham Road, London, S.W.3.

A CONFERENCE on the Rheology of Disperse Systems, organized by the British Society of Rheology, will be held in the Natural Sciences Building of the University College of Swansea, Singleton Park, Swansea, during September 19-21. Accommodation has been arranged at the University hall of residence. Further details can be obtained from the Hon. Secretary of the British Society of Rheology, Mr. N. Wookey, 52 Tavistock Road, Edgware, Middlesex.

A CONFERENCE on "Operational Research" has been organized by the Operational Research Society (United Kingdom), the Operations Research Society of America and the Institute of Management Sciences (New York), and will be held in Oxford during September 2-6. About 250 delegates from twenty countries are expected, and reprints of the papers to be presented have been prepared. The Conference Secretary is Miss B. Kornitzer, 6 Gray's Inn Square, London, W.C.1.

ERratum. In the communication entitled "The Free Energy of Hydrolysis of Adenosine Triphosphoric Acid" in Nature of June 29, p. 1350, the factor $10^{3}$ was omitted from col. 8 of the table. The equilibrium constants for the hexokinase reaction should read $1.380 \times 10^{3}$ and similarly down that column. 